\title{
LEVELS OF MINERALS IN SERA OF CHICKENS SUFFERING FROM MAREK'S DISEASE
}

\author{
J. JURAJDOVÁ \\ Department of Diagnostics, Therapy and Prevention, University of Veterinary Science, \\ 61242 Brno
}

Received fune 21, 1977

\begin{abstract}
Jurajdová J.: Levels of Minerals in Sera of Chickens Suffering from Marek's Disease. Acta vet. Brno, 47, 1978: 189-196.

The concentrations were studied of sodium, potassium, calcium, magnesium and phosphorus as well as the correlations and coefficients of their level ratios in sera of RIR chickens 56 days after infection with Marek's disease virus, and they were compared with the controls.

In the infected chickens a reduction of the concentration of calcium was observed, with the exception of chickens suffering from tumors, and an increased concentration of magnesium which was the highest in chickens with tumors. In chickens with tumors a reduced phosphorus level was observed, while in those with macroscopically unchanged kidneys also a decrease in the sodium concentration was found.

In infected chickens the coefficient of the $\mathrm{Ca} / \mathrm{Mg}$ ratio was reduced and reached its maximum value in tumorous chickens. Correlations between calcium and phosphorus found in control chickens were not proved in the infected chickens and no other were observed.
\end{abstract}

Marek's disease, chickens, serum, mineral substances.

Properties of the internal milieu of the organism were maintained in values optimal for cel and tissue activity. The stability of the internal milieu is ensured through the activity of many complicated regulation mechanisms under the direct coaction of biocatalysts among which we include mineral substances as well.

Studies dealing with the importance of mineral substances in proteosynthesis (Greger and Schwartz 1974; Rubin 1975), oncogenicity (Zýka 1972; Šula 1974; Anast et al. 1975; Brennan et al. 1976) or with the effect of chelates in in vitro experiments on the yield of Marek's disease virus (Aldinger and Calnek 1971) led us to studies of the metabolism of mineral substances in Marek's disease in in vivo experiments with chickens.

\section{Material and Methods}

\section{Experimental chickens}

Experiments were carried out with one-day-old chickens of Sykes Line B Rhode Island Red (RIR) from the Institute of Molecular Genetics of the Czechoslovak Academy of Sciences in Prague, susceptible to infection with the Marek's disease virus (Biggs et al. 1968). Chickens were infected aerogenically with dust from an enterprise with a permanent occurrence of acute Marek's disease (MD) and stored for 95-118 days after collection under laboratory temperature in a way described earlier (Jurajda and Klimeš 1970). The infectiousness of the dust was proved by in vitro examinations in cell cultures of chicken kidneys $-7.25 \times 10^{2} \mathrm{PFU} / \mathrm{g}$ of dust (Hložánek et al. 1976). 


\section{Preparation of the cutaneous MD-antigen}

Feathers from the MD-positive chickens with tumors, infected with the MD virus earlier, were cut off as nearest to the skin as possible in such a way as to leave the quill shaft in the skin. A $20 \%(w / v)$ homogenate in a buffered physiological solution (BPS, pH 7.2) was prepared from the skin with an addition of $0.2 \%$ of EDTA (Chelaton III) and antibiotics. After three repeated cycles of freezing and thawing (mixture of solid $\mathrm{CO}_{2}$ in methylalcohol and water bath at $37^{\circ} \mathrm{C}$ ) the homogenate was centrifuged for 15 minutes at $1.000 \mathrm{~g}$. The supernatant was divided into ampules of $0.5 \mathrm{ml}$ each and stored at $-60^{\circ} \mathrm{C}$ in dry ice and served as a positive MD skin antigen for preparation in agar gel test.

\section{Agar gel precipitation (AGP) test}

Used was a double diffusion according to Ouchterlony in Petri dishes of $10 \mathrm{~cm}$ in diameter filled with agar according to Okazaki et al. (1970): $1 \%$ of Noble agar (Difco) in a NaK phosphate buffer with $8 \%$ of $\mathrm{NaCl}, \mathrm{pH}$ 7.4. The central well was filled with the MD skin antigen and the marginal wells with sera tested. Petri dishes were stored in an atmosphere saturated with water vapours at a laboratory temperature and results were read after 24 and 48 hours. A serum from the MD-positive chickens with tumors earlier infected with a MD virus served as a control.

\section{Biochemical examinations}

After finishing the experiments the chickens were killed by bleeding out and the concentrations of macro-elements ( $\mathrm{Na}, \mathrm{K}, \mathrm{Ca}$ and $\mathrm{Mg}$ ) in the serum were determined using the method of atomic absorption spectrophotometry on an Atomspek apparatus of the firm Hilger and Watts and photometrically $(P)$ using Bio/Lachema tests as described in earlier studies (Jurajdová 1978). From the values measured the coefficients were calculated of ratios of levels of the individual elements. Statistical evaluation of the results and correlations of the levels of the individual elements was done using a Hewlett Packard computer, 9810A model, by means of Duncan's and Student's $t$-test.

\section{Experimental procedure}

Aerogenically infected were 264 chickens (i. e. 135 females and 129 males); 71 chickens served as controls ( 36 females and 35 males). Both groups were kept in isolation, fed complete mixtures for chickens BR I-start, and given water ad libitum. Chickens which died during the experiment were dissected and results of the dissections were recorded. After finishing the experimentt 56 days after infection, the chickens were examined for the presence of macroscopic changes or MD-precipitation antibodies; according to the results they were divided into 5 groups: (1) control, (2) infected but with no macroscopical changes and MD-precipitation antibodies (MD-neg), (3) with MD-precipitation antibodies (MD-Ab), (4) with macroscopical changes (AGP was not performed) (MD-tum), and (5) MD-positive (MD-pos), including groups (3) and (4). The features investigated were then mutually compared in all groups, also with regard to the effect of sex.

Table 1

Occurrence of Marek's disease (MD) in infected RIR chickens

\begin{tabular}{|c|c|c|c|c|c|c|c|c|c|c|c|c|c|c|}
\hline & \multicolumn{2}{|c|}{ Mortality $^{1}$ ) } & \multicolumn{2}{|c|}{$\%$} & \multicolumn{2}{|c|}{ Tumors $^{2}$ ) } & $\%$ & \multicolumn{2}{|c|}{$\left.\mathrm{AGP}^{3}\right)$} & \multicolumn{2}{|c|}{$\%$} & \multicolumn{2}{|c|}{ Total MD } & $\%$ \\
\hline \multirow[t]{3}{*}{$\begin{array}{l}\text { Fema'es } \\
\text { Males } \\
\text { Chickens }\end{array}$} & \multicolumn{2}{|c|}{$\begin{array}{l}\left.14 / 135^{4}\right) \\
12 / 129 \\
26 / 264\end{array}$} & \multicolumn{2}{|c|}{$\begin{array}{r}10.37 \\
9.30 \\
9.85\end{array}$} & \multicolumn{2}{|c|}{$\begin{array}{l}21 / 121 \\
17 / 117 \\
38 / 238\end{array}$} & $\begin{array}{l}17.36 \\
14.53 \\
15.97\end{array}$ & \multicolumn{2}{|c|}{$\begin{array}{r}77 / 100 \\
80 / 100 \\
157 / 200\end{array}$} & \multicolumn{2}{|c|}{$\begin{array}{l}77.00 \\
80.00 \\
78.50\end{array}$} & \multicolumn{2}{|c|}{$\begin{array}{l}112 / 135 \\
109 / 129 \\
221 / 264\end{array}$} & $\begin{array}{l}82.96 \\
84.50 \\
83.71\end{array}$ \\
\hline & \multirow{2}{*}{$\begin{array}{c}\text { Number } \\
\text { investigated }\end{array}$} & \multicolumn{11}{|c|}{ Occurrence and localization of tumorous changes } & \multirow{2}{*}{\multicolumn{2}{|c|}{$\begin{array}{l}\varnothing \text { time of } \\
\text { mortality } \\
\text { (days) }\end{array}$}} \\
\hline & & \multicolumn{2}{|c|}{ Liver } & \multicolumn{2}{|c|}{ Gonads } & Kidneys & Spleen & Lungs & \multicolumn{2}{|c|}{$\begin{array}{l}\text { Proven- } \\
\text { triculus }\end{array}$} & \multicolumn{2}{|c|}{ Muscle } & & \\
\hline $\begin{array}{l}\text { Females } \\
\text { Males } \\
\text { Chickens }\end{array}$ & $\begin{array}{l}35 \\
29 \\
64\end{array}$ & $\begin{array}{l}21 \\
17 \\
38\end{array}$ & & & & $\begin{array}{l}24 \\
24 \\
48\end{array}$ & $\begin{array}{l}19 \\
17 \\
36\end{array}$ & $\begin{array}{l}2 \\
2 \\
4\end{array}$ & & $\begin{array}{l}8 \\
5 \\
3\end{array}$ & & 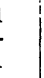 & & \\
\hline
\end{tabular}

1) All died birds had tumors

2) Occurrence of tumorous changes in chicks surviving and investigated at the end of the experiment

s) Occurrence of MD-precipitation antibodies in chicks investigated at the end of the experiment

4) Number of positive/ number of investigated 


\section{Results and Discussion}

A survey of the occurrence of Marek's disease in infected RIR chickens is given in Table 1. The average levels of minerals (in mmol/1), coefficients, and correlations of their levels in sera of control and infected chickens are given in Tables $2-4$.

Table 2

Average levels of minerals ( $\mathrm{mmol} / \mathrm{l}$ ), coefficients and correlations of their levels in sera of experimental RIR females

\begin{tabular}{|c|c|c|c|c|c|}
\hline Minerals & Natrium (Na) & Kalium (K) & Calcium (Ca) & Magnesium (Mg) & Phosphorus (P) \\
\hline $\begin{array}{l}\text { Control } \\
\text { MD-neg } \\
\text { MD-Ab } \\
\text { MD-tum } \\
\text { MD-pos }\end{array}$ & $\begin{array}{l}149.46 \pm 0.92 \\
147.27 \pm 1.57 \\
148.29 \pm 1.66 \\
\left.\left.142.38 \pm 2.42^{3}\right)^{3}\right) \\
147.02 \pm 0.84\end{array}$ & $\begin{array}{l}6.56 \pm 0.22 \\
5.92 \pm 0.33 \\
6.22 \pm 0.13 \\
6.50 \pm 0.32 \\
6.28 \pm 0.12\end{array}$ & $\begin{array}{l}2.67 \pm 0.04 \\
\left.2.46 \pm 0.05^{1}\right) \\
\left.2.44 \pm 0.03^{2}\right) \\
2.48 \pm 0.09 \\
\left.2.45 \pm 0.03^{1}\right)\end{array}$ & $\begin{array}{l}0.94 \pm 0.01 \\
0.98 \pm 0.02 \\
\left.1.01 \pm 0.01^{1}\right) \\
\left.1.02 \pm 0.03^{1}\right) \\
1.01 \pm 0.01\end{array}$ & $\begin{array}{l}2.71 \pm 0.07 \\
2.51 \pm 0.10 \\
2.65 \pm 0.05 \\
2.52 \pm 0.11 \\
2.62 \pm 0.05\end{array}$ \\
\hline $\begin{array}{l}\text { Coef- } \\
\text { ficient } \$\end{array}$ & $\mathrm{Na} / \mathrm{K}$ & $\mathrm{K} / \mathrm{Ca}$ & $\mathrm{Ca} / \mathrm{Mg}$ & $\mathrm{Ca} / \mathbf{P}$ & $\mathrm{K} / \mathrm{Mg}$ \\
\hline $\begin{array}{l}\text { Control } \\
\text { MD-neg } \\
\text { MD-Ab } \\
\text { MD-tum } \\
\text { MD-pos }\end{array}$ & $\begin{array}{l}23.28 \pm 0.82 \\
26.10 \pm 1.66 \\
24.66 \pm 0.57 \\
22.83 \pm 1.03 \\
24.26 \pm 0.50\end{array}$ & $\begin{array}{l}2.44 \pm 0.08 \\
2.40 \pm 0.10 \\
2.56 \pm 0.06 \\
2.66 \pm 0.16 \\
2.58 \pm 0.06\end{array}$ & $\begin{array}{l}2.86 \pm 0.05 \\
\left.2.54 \pm 0.08^{2}\right) \\
\left.2.45 \pm 0.05^{2}\right) \\
\left.2.40 \pm 0.11^{2}\right) \\
\left.2.44 \pm 0.04^{2}\right)\end{array}$ & $\begin{array}{l}1.11 \pm 0.02 \\
1.11 \pm 0.04 \\
1.06 \pm 0.03 \\
1.11 \pm 0.06 \\
1.07 \pm 0.02\end{array}$ & $\begin{array}{l}7.02 \pm 0.22 \\
\left.6.06 \pm 0.34^{1}\right) \\
\left.6.20 \pm 0.14^{8}\right) \\
6.52 \pm 0.32 \\
\left.6.28 \pm 0.12^{1}\right)\end{array}$ \\
\hline $\begin{array}{l}\text { Correla- } \\
\text { tion }(r)\end{array}$ & $\mathrm{Na} / \mathrm{K}$ & $\mathrm{K} / \mathrm{Ca}$ & $\mathrm{Ca} / \mathrm{Mg}$ & $\mathrm{Ca} / \mathrm{P}$ & $\mathrm{K} / \mathrm{Mg}$ \\
\hline $\begin{array}{l}\text { Control } \\
\text { MD-neg } \\
\text { MD-Ab } \\
\text { MD-tum } \\
\text { MD-pos }\end{array}$ & $\begin{array}{l}-0.0253 \\
0.5920^{* *} \\
0.1639 \\
0.0632 \\
0.0960\end{array}$ & $\begin{array}{l}0.4965^{* *} \\
0.6381^{* *} \\
0.1344 \\
0.3319 \\
0.1942\end{array}$ & $\begin{array}{r}0.4299^{*} \\
0.1212 \\
-0.2246 \\
0.2582 \\
-0.0831\end{array}$ & $\begin{array}{c}0.6738^{* *} \\
0.5643^{* *} \\
-0.3210^{* *} \\
0.1925 \\
-0.1932\end{array}$ & $\begin{array}{l}0.3550^{*} \\
0.1701 \\
0.1894 \\
0.2827 \\
0.2254^{*}\end{array}$ \\
\hline
\end{tabular}

1) Significant difference as compared with control at $P<0.05$

2) Significant difference as compared with control at $P<0.01$

3) Significant difference as compared with group with $M D$-precipitation antibodies $(M D-A b)$ at $P<0.01$

§) Mean \pm standard error of mean

* Significant at $P \cdot<0.05$

** Significant at $P<0.01$

The occurrence of MD in experimental RIR chickens after infection with dust containing the $M D$ virus was similar as after infection with other strains of acute MD (Purchase and Biggs 1967; Eidson and Schmittle 1968; Bankowski et al. 1969, and others). In contradistinction to the affinity of the acute MD virus to the gonad tissue (Biggs and Payne 1967; Chomiak et al. 1967; Purchase and Biggs 1967) found most often were tumorous changes in the kidneys, liver and spleen. The total occurrence of tumorous changes was lower than described in the RIR chickens after infection with acute strains of HPRS (Biggs et al. 1965; Purchase and Biggs 1967).

The differences from $\mathrm{Na}$ concentrations in the serum of control groups were observed only in MD-tumorous bird. In females a decrease of $4.74 \%(p<0.01)$ was observed, and in chickens in total it was $3.05 \%(p<0.01)$. With regard to the importance of kidneys as the main organ of $\mathrm{Na}$ excretion, we observed the $\mathrm{Na}$ levels in the serum of these birds with regard to the macroscopical affection of the kidneys. It was found that the level of $\mathrm{Na}$ in the serum of birds with kidneys afflicted with tumors did not differ from the controls. On the other hand, the so- 
Table 3

Average levels of minerals ( $m m \mathrm{~m} / / 1)$, coefficients and correlations of their levels in sera of experimental RIR males

\begin{tabular}{|c|c|c|c|c|c|}
\hline Minerals & Natrium (Na) & Kalium (K) & Calcium $(\mathrm{Ca})$ & Magnesium (Mg) & Phosphorus (P) \\
\hline $\begin{array}{l}\text { Control } \\
\text { MD-neg } \\
\text { MD-Ab } \\
\text { MD-tum } \\
\text { MD-pos }\end{array}$ & $\begin{array}{l}148.97 \pm 0.88 \\
148.50 \pm 1.37 \\
148.19 \pm 0.77 \\
147.47 \pm 2.11 \\
148.06 \pm 0.73\end{array}$ & $\begin{array}{l}6.37+0.20 \\
6.56 \pm 0.24 \\
5.92 \pm 0.13 \\
6.43 \pm 0.34 \\
6.01 \pm 0.12\end{array}$ & $\begin{array}{l}2.63 \pm 0.03 \\
\left.2.38 \pm 0.07^{2}\right) \\
\left.2.46 \pm 0.03^{2}\right) \\
\left.2.59 \pm 0.06^{3}\right) \\
\left.2.48 \pm 0.03^{2}\right)\end{array}$ & $\begin{array}{l}0.97 \pm 0.01 \\
1.02 \pm 0.01 \\
\left.1.03 \pm 0.01^{1}\right) \\
\left.\left.1.12 \pm 0.06^{2}\right)^{3}\right)^{6} \\
\left.1.04 \pm 0.01^{1}\right)\end{array}$ & $\begin{array}{l}2.73 \pm 0.06 \\
2.93 \pm 0.11 \\
\left.2.59 \pm 0.05^{3}\right) \\
\left.\left.2.42 \pm 0.13^{1}\right)^{4}\right) \\
\left.2.56 \pm 0.05^{3}\right)\end{array}$ \\
\hline $\begin{array}{c}\text { Coef- } \\
\text { ficient S }\end{array}$ & $\mathrm{Na} / \mathrm{K}$ & $\mathrm{K} / \mathrm{Ca}$ & $\mathrm{Ca} / \mathbf{M g}$ & $\mathrm{Ca} / \mathbf{P}$ & $\mathrm{K} / \mathbf{M g}$ \\
\hline $\begin{array}{l}\text { Control } \\
\text { MD-neg } \\
\text { MD-Ab } \\
\text { MD-tum } \\
\text { MD-pos }\end{array}$ & $\begin{array}{l}23.78 \pm 0.82 \\
23.64 \pm 0.85 \\
26.05 \pm 0.64 \\
23.70 \pm 1.19 \\
25.65 \pm 0.57\end{array}$ & $\begin{array}{l}2.42 \pm 0.08 \\
2.82 \pm 0.16 \\
2.44 \pm 0.06 \\
2.48 \pm 0.12 \\
2.44 \pm 0.06\end{array}$ & $\begin{array}{l}2.75 \pm 0.05 \\
\left.2.36 \pm 0.10^{2}\right) \\
\left.2.41 \pm 0.05^{2}\right) \\
\left.2.39 \pm 0.13^{2}\right) \\
\left.2.41 \pm 0.05^{2}\right)\end{array}$ & $\begin{array}{l}1.09 \pm 0.03 \\
0.96 \pm 0.05 \\
\left.1.10 \pm 0.03^{3}\right) \\
\left.\left.1.24 \pm 0.06^{4}\right)^{5}\right) \\
\left.1.13 \pm 0.03^{3}\right)\end{array}$ & $\begin{array}{l}6.70 \pm 0.20 \\
6.48 \pm 0.26 \\
\left.5.80 \pm 0.144^{2}\right) \\
6.00 \pm 0.48 \\
\left.5.82 \pm 0.14^{2}\right)\end{array}$ \\
\hline $\begin{array}{l}\text { Correla- } \\
\text { tion }(r)\end{array}$ & $\mathrm{Na} / \mathrm{K}$ & $\mathrm{K} / \mathrm{Ca}$ & $\mathrm{Ca} / \mathrm{Mg}$ & $\mathrm{Ca} / \mathrm{P}$ & $\mathrm{K} / \mathbf{M g}$ \\
\hline $\begin{array}{l}\text { Control } \\
\text { MD-neg } \\
\text { MD-Ab } \\
\text { MD-tum } \\
\text { MD-pos }\end{array}$ & $\begin{array}{r}-0.2919 \\
0.2379 \\
0.1388 \\
0.2097 \\
0.1395\end{array}$ & $\begin{array}{c}0.3304 \\
-0.0759 \\
0.1883 \\
0.4707 \\
0.2778^{* *}\end{array}$ & $\begin{array}{l}0.1013 \\
-0.4749^{*} \\
-0.1805 \\
-0.2427 \\
-0.1056\end{array}$ & $\begin{array}{r}0.3715^{*} \\
-0.2326 \\
-0.0772 \\
0.2582 \\
-0.0220\end{array}$ & $\begin{array}{c}-0.0149 \\
-0.0584 \\
0.3205 * * \\
-0.3883 \\
0.1314\end{array}$ \\
\hline
\end{tabular}

1) Significant difference as compared with control at $P<0.05$

2) Significant difference as compared with control at $P<0.01$

3) Significant difference as compared with MD-negative (MD-neg) group at $P<0.05$

4) Significant difference as compared with MD-negative group at $P<0.01$

5) Significant difference as compared with group with $M$ D-precipitation antibodies (MD-Ab) at $P<0.05$

-) Significant difference as compared with group with MD-precipitation antibodies (MD-Ab) at $P<0.01$

Mean \pm standard error of mean

* Significant at $P<0.05$

** Significant at $P<0.01$

dium concentration (137 and $139.7 \mathrm{mmol} / \mathrm{l}$ ) in females and in chickens in total, resp., with macroscopically unchanged kidneys but with tumors of other visceral organs was found to differ significantly from control values $(P<0.01)$. The effect of the degree of affliction of kidneys was observed also in other features but with a negative result.

The level of potassium in the serum of infected birds did not reveal and deviations from the control values, the only exception being a lower concentration of $\mathrm{K}$ in chickens with MD-precipitation antibodies by $6.18 \%$ as compared with controls $(P<0.05)$.

The most evident changes of mineral concentrations in the serum of MD-infected birds were observed in calcium and magnesium. The Ca level was decreased in MD-negative birds (in chickens by $8.66 \%$ ) and bird with precipitation antibodies (in chickens by $7.53 \%$ ), while in birds afflicted with tumors the Ca concentration did not differ from that of controls. In magnesium, on the contrary, an increase was observed in the group of birds with MD-predicitation (in chickens by $6.67 \%$ ), the maximum occurring in birds afflicted with tumors. Significant was also the difference in $\mathrm{Mg}$ concentrations in the serum of females and males afflicted with tumors.

Lansing et al. (1948) found a lower Ca content in the tumorous tissue as compared with a healthy tissue. The reduction of the level of serum albumin observed together with some kidney afflictions is sometimes accompanied with 
Table 4

Average levels of minerals (mmol/1), coefficients and correlations of their levels in sera of experimental RIR chickens

\begin{tabular}{|c|c|c|c|c|c|}
\hline Mineral§ & Natrium (Na) & Kalium (K) & Calcium (Ca) & Magnesium (Mg) & Phosphorus (P) \\
\hline $\begin{array}{l}\text { Control } \\
\text { MD-neg } \\
\text { MD-Ab } \\
\text { MD-tum } \\
\text { MD-pos }\end{array}$ & $\begin{array}{l}149.21 \pm 0.63 \\
147.82 \pm 1.04 \\
148.24 \pm 0.55 \\
\left.\left.144.66 \pm 1.65^{2}\right)^{4}\right) \\
147.54 \pm 0.56\end{array}$ & $\begin{array}{l}6.47 \pm 0.15 \\
6.22 \pm 0.21 \\
6.07 \pm 0.091) \\
6.47 \pm 0.23 \\
6.15 \pm 0.09\end{array}$ & $\begin{array}{l}2.65 \pm 0.03 \\
\left.2.42 \pm 0.04^{2}\right) \\
\left.2.45 \pm 0.02^{2}\right) \\
2.54 \pm 0.05 \\
\left.2.47 \pm 0.02^{2}\right)\end{array}$ & $\begin{array}{l}0.96 \pm 0.01 \\
1.00 \pm 0.01 \\
\left.1.02 \pm 0.01^{2}\right) \\
\left.\left.\left.1.07 \pm 0.07^{2}\right)^{3}\right)^{5}\right) \\
\left.1.03 \pm 0.01^{3}\right)\end{array}$ & $\begin{array}{l}2.72 \pm 0.04 \\
\left.2.69 \pm 0.07^{5}\right) \\
2.62 \pm 0.03 \\
2.47 \pm 0.08 \text { ) } \\
2.59 \pm 0.03\end{array}$ \\
\hline $\begin{array}{c}\text { Coef- } \\
\text { ficient } \$\end{array}$ & $\mathbf{N a} / \mathbf{K}$ & $\mathbf{K} / \mathbf{C a}$ & $\mathrm{Ca} / \mathrm{Mg}$ & $\mathrm{Ca} / \mathrm{P}$ & $\mathrm{K} / \mathbf{M g}$ \\
\hline $\begin{array}{l}\text { Control } \\
\text { MD-neg } \\
\text { MD-Ab } \\
\text { MD-tum } \\
\text { MD-pos }\end{array}$ & $\begin{array}{l}23.53 \pm 0.57 \\
24.97 \pm 0.97 \\
\left.25.37 \pm 0.43^{1}\right) \\
\left.23.20 \pm 0.76^{4}\right) \\
24.95 \pm 0.38\end{array}$ & $\begin{array}{l}2.42 \pm 0.04 \\
2.60 \pm 0.10 \\
2.50 \pm 0.04 \\
2.58 \pm 0.10 \\
2.52 \pm 0.94\end{array}$ & $\begin{array}{l}2.81 \pm 0.04 \\
\left.2.45 \pm 0.06^{2}\right) \\
\left.2.43 \pm 0.03^{2}\right) \\
\left.2.39 \pm 0.08^{2}\right) \\
\left.2.42 \pm 0.03^{2}\right)\end{array}$ & $\begin{array}{l}1.10 \pm 0.02 \\
1.05 \pm 0.03 \\
1.08 \pm 0.02 \\
\left.\left.1.18 \pm 0.04^{3}\right)^{4}\right) \\
1.10 \pm 0.02\end{array}$ & $\begin{array}{l}6.86 \pm 0.14 \\
6.26 \pm 0.22 \\
\left.6.00 \pm 0.10^{2}\right) \\
6.28 \pm 0.28 \\
\left.6.06 \pm 0.10^{2}\right)\end{array}$ \\
\hline $\begin{array}{l}\text { Correla- } \\
\text { tion (r) }\end{array}$ & $\mathrm{Na} / \mathrm{K}$ & $\mathbf{K} / \mathbf{C a}$ & $\mathrm{Ca} / \mathrm{Mg}$ & $\mathrm{Ca} / \mathbf{P}$ & $\mathbf{K} / \mathbf{M g}$ \\
\hline $\begin{array}{l}\text { Control } \\
\text { MD-neg } \\
\text { MD-Ab } \\
\text { MD-tum } \\
\text { MD-pos }\end{array}$ & $\begin{array}{c}-0.1461 \\
0.4911 * * \\
0.1503 \\
0.1507 \\
0.1075\end{array}$ & $\begin{array}{l}0.4424 * * \\
0.2632 \\
0.1583 \\
0.3699 * \\
0.2284^{* *}\end{array}$ & $\begin{array}{c}0.2826 * \\
-0.1874 \\
-0.1870 * \\
0.0102 \\
-0.1002\end{array}$ & $\begin{array}{c}0.5501^{* *} \\
0.2031 \\
-0.2015^{*} \\
0.1846 \\
-0.1231\end{array}$ & $\begin{array}{l}0.1527 \\
0.1363 \\
0.2459 * * \\
-0.0863 \\
0.1543\end{array}$ \\
\hline
\end{tabular}

1) Significant difference as compared with control at $P<0.05$

2) Significant difference as compared with control at $P<0.01$

3) Significant difference as compared with MD-negative (MD-neg) group at $P<0.05$

5) Significant difference as compared with group with $\mathrm{MD}$-precipitation antibodies (MD-Ab) at $P<0.05$

5) Significant difference between sexes in group at $P<0.05$

$\checkmark$ Mean \pm standard error of mean

* Significant at $P<0.05$

** Significant at $P<0.01$

a reduction of the level of serum Ca (Mazur and Harrow 1971). Samadieh et al. (1969), Washburn and Eidson (1970), Bankowski et al. (1970), and Fletcher et al. (1972) described the reduced level of serum albumin in MD-positive chickens. However, this does not correspond with our findings in birds with macroscopically changed kidneys in which the values of serum Ca did not differ from the controls.

The metabolism of calcium and magnesium is closely related with regard to their common mechanism of resorption in the intestine and renal tubules. Mutual competition of $\mathrm{Ca}$ and $\mathrm{Mg}$ in the organism appears with the insufficiency of one ion by increasing the concentration of the other. Besides a decreased capacity of the kidneys to excrete magnesium, also the affliction of liver and suprarenal gland leads to an increase of the plasmatic magnesium level. Hypermagnesemia occurs often due to the transmission of $\mathrm{Mg}$ between the intra and extra-cellular space, i. e. magnesium from the cells due to cellular catabolism (Fencl 1960; Kapitola and Kü chel 1968). A more detailed explanation of the causes of hypocalcemia and hypermagnesemia in MD-positive birds calls for further investigations and studies.

The concentration of phosphorus in the serum of infected birds decreased only in males afflicted with tumors (by $11.53 \%$ ) and in chickens in total (by $9.05 \%$ ). The effect of sex on the $P$ level in serum was recorded only in the MD-negative group, even though the $P$ concentrations found did not themselves differ from the control values. 
With regard to the decrease of the Ca concentration observed and increase of $\mathrm{Mg}$ in the serum of infected birds, also the coefficient of the $\mathrm{Ca} / \mathrm{Mg}$ ratio decreased, at the same time a maximum decrease was observed in birds afflicted with tumors (in chickens by $14.95 \%$ ). Alexandrowicz et al. (1970) observed a similar decrease of the $\mathrm{Ca} / \mathrm{Mg}$ ratio coefficient in leukemic cows (2.68) as compared with healthy animals (3.20).

The increase of magnesium concentration in the serum probably affected also the decrease of the $\mathrm{K} / \mathrm{Mg}$ ratio coefficient in the serum of birds with MD-precipitation antibodies (by $12.63 \%$ ), even though the change of $\mathrm{K}$ in the serum of this group of birds was not expressive. Close relationships between potassium and magnesium, attributed to their mutual intracellular deposition and to some common regulation mechanisms, are considerably variable and probably depend also on the condition of the organism as well as on the actual concentration of both ions (Kapitola and Küchel 1968). According to Zýka (1972) the disturbance of the $\mathrm{K} / \mathrm{Mg}$ ratio is considered to be a carcinogenic factor.

Correlations of greater significance were observed in the control group only in females $(r=0.6738$ at $P<0.01)$ and then in total in chickens $(r=0.5501$ at $P<0.01$ ) between $\mathrm{Ca}$ and $P$ levels. In infected birds this correlation was expressed only in MD-negative females $(r=0.5643)$; in addition, in some cases we found positive correlations between $\mathrm{Na} / \mathrm{K}(r=0.5920)$ and $\mathrm{K} / \mathrm{Ca}(r=0.6381)$ levels. In the remaining groups of infected birds, the correlations between the studied levels of minerals were minimum to non-significant.

Results obtained in infected RIR chickens indicated that in the course of Marek's disease the metabolism of mineral substances was also affected. A more detailed explanation of the deviations found (as compared with control values) calls for further investigations and studies to say nothing of the necessity of a thorough analysis of the metabolism of mineral substances in healthy poultry.

\section{Hladiny minerálii $v$ sérech kuřat postižených Markovou nemocí (MN)}

V práci byly sledovány koncentrace sodíku, draslíku, vápníku, hořčíku a fosforu, korelace a koeficienty poměrů jejich hladin v sérèch kuřat RIR za 56 dní po infekci prachem obsahujícím virus Markovy nemoci a porovnávány $\mathrm{s}$ hodnotami kontrolními.

Vzorky séra byly vyšetřovány na atomovém absorpčním spektrofotometru Atomspek fy Hilger \& Watts. Fosfor byl určován fotometricky pomocí Bio-Lachema testü.

$\mathrm{U}$ infikovaných kuřat došlo $\mathrm{k}$ určitým změnám $\mathrm{v}$ koncentracích jednotlivých prvků oproti kontrolním hodnotám a výše těchto změn byla ovlivňována stupněm postižení organismu. Hladina vápníku $\mathrm{v}$ séru byla snižena $\mathrm{u}$ všech sledovaných skupin mimo kuřata $s$ nádorovitými změnami a hladina hořčíku byla naopak zvýšena mimo skupinu kuřat infikovaných, ale $M N$-negativních. Maximální zvýšení hladiny magnesia $\mathrm{v}$ séru bylo pozorováno $\mathrm{u}$ kur̆at $\mathrm{s}$ nádorovitými změnami. $\mathrm{U}$ těchto kuřat bylo také zjišstěno snižení hladiny fosforu $\mathrm{v}$ séru a u kuřat $\mathrm{s}$ nádory, ale bez makroskopického postižení ledvin i snižení koncentrace sodíku $\mathrm{v}$ séru. Rozdílné hodnoty vlivem pohlaví byly pozorovány u fosforu $v$ MN-negativní skupině a u hořčíku u kuřat $s$ nádorovitými změnami.

Koeficient poměru hladin vápníku a hořčíku byl snižen u všech infikovaných kuřat a maxima dosáhl u kuřat s nádorovitými změnami. Vzestup koncentrace hořčíku v séru ovlivnil pravděpodobně i pokles koeficientu poměru $\mathrm{K} / \mathrm{Mg}$ v séru kư̌at 
s $M N$-precipitačními protilátkami, i když změna koncentrace kalia $v$ séru u této skupiny nebyla tak výrazná.

Korelační vztahy vápníku a fosforu zjištěné u kontrolní skupiny nebyly u $\mathrm{MN}$ -pozitivních kuřat potvrzeny a jiné pozorovány nebyly.

Výskyt Markovy nemoci u pokusných kuřat RIR se lišil vyšším výskytem nádorovitě postižených ledvin, jater a sleziny na úkor postižení gonád oproti popisovaným vlastnostem jiných kmenů akutní formy Markovy nemoci.

\section{Урсвни минеральных веществ в сыворотках цыплят, заболевших болезнью Марека (БМ)}

В работе проводились наблюдения концентрации натрия, кальция, калия, магния и фосфора, корреляции и коэффициенты соотношения их уровней в сыворотках цыплят РИР спустя 56 дней после инфекции пылью, содержащеь вирус болезни Марека, и проводились сравнения с контрольными величинами.

Образцы сыворотки обследовались с помощью атомного абсорбционного спектрофотометра Атомспек фирмы Хайлгери Уоттс. Фосфор определялся фотометрически с помощью Био-Лахема тестов.

У зараженных цыплят наблюдались определенные изменения конщентрации отдельных әлементов по сравнению с контрольными величинами и уровень настоящих изменений находился под влиянием степени пострадация организма. У ровень кальция в сыворотке у всех находящихся под наблюдением групп помимо цыплят с опухольными изменениями был пониженным и наоборот, уровень магния, помимо зараженных, но отрицательных к БМ цыпляа, был повышенным. Максимальное увеличение уровня магния в сыворотке цыплят наблюдалось у цыплят с опухольными изменениями. В данном случае был выявлен пониженный уровень фосфора в сыворотке и у цыплят с опухолями, однако, без макроскопического изменения почек и понижения концентрации натрия в сыворотке. Разные величины вследствие половой разницы наблюдались у фосфора в БМ отрицательной группе и магния в случае цыплят с опухольными изменениями.

Коэффициент соотношения уровней кальция и магния был пониженным у всех зараженных цыплят и достиг максимума у цыплят с опухольными изменениями. Повышение концентрации магния в сыворотке находилось, вероятно, под влиянием понижения коэффицента соотношения калий/магний в сыворотке цыплят с БМ преципитационными антителами, хотя и зменение концентрации калия в сыворотке в случае данной группы было не столь выразительным.

\section{References}

ADLDINGER, H. K. - CALNEK, B. W.: An improved in vitro assay for cell-free Marek's disease virus. Arch. ges. Virusforsch., 34, 1971: 391-395.

ALEKSANDROWICZ, J. - WÓJCIK, K. - BAROWICZ, T.: Badania zawartozci $\mathrm{Mg}$ i Ca w surowicy krwi krów ze stada „,bislaczkowego“ i ,wolnego“" od bislacki. Med. veter., 26, 1970: $721-725$.

ANAST, C. - DAVID, L. - WINNACKER, J. et al.: S rum calcitonin-lowering effect of magnesium in patients with medullary carcincma of the thyroid. J. Clin. Invest., 56, 1975: 1615$-1621$.

BANKOWSKI, R. A. - MOULTON, J. E. - MIKAMI, T.: Characterization of Cal-1 strain of acute Marek's disease agent. Am. J. Vet. Res., 30, 1969: 1667-1676. 
BANKOWSKI, R. A. - MIKAMI, T. - REYNOLDS, B.: The relation between infection of chickens with Marek's disease and the presence of precipitin antibodies. Avian Dis., 14, 1970: $723-737$.

BIGGS, P. M. - PURChASE, H. G. - BEE, B. R. - DALTON, P. J.: Preliminary report on acute Marek's disease (fowl paralysis) in Great Britain. Vet. Rec., 77, 1965: 1339-1340.

BIGGS, P. M. - PAYNE, L. N.: Studies on Marek's disease. I. Experimental transmission. J. Nat. Cancer Inst., 39, 1967: 267-280.

BIGGS, P. M. - THORPE, R. J. - PAYNE, L. N.: Studies on genetic resistance to Marek's disease in the domestic chicken. Brit. Poult. Sci., 9, 1968: 37-52.

BRENNAN, J. K. - LICHTMAN, M. A. - CHAMBERLAIN, J. K. - LEBLOND, P.: Isolation of variant lymphoma cells with reduced growth requirements for extracellular calcium and magnesium and enhanced oncogenicity. Blood 47, 1976: 447-459.

CHOMIAK, T. W. - LUGINBUHL, R. E. - HELMBOLDT, C. F. - KOTTARIDIS, S. D.: Marek's disease. I. Propagation of the Connecticut A (Conn-A) isolate in chicks. Avian Dis., 11, 1967: 646-653.

EIDSON, C. S. - SCHMITTLE, S. C.: Studies on acute Marek's disease. I. Characteristics of isolate GA in chickens. Avian Dis., 12, 1968: 467-476.

FENCL, V.: Patofyziologie vody a elektrolytů při akutním selhání ledvin. Cas. lék. čes., 26, 1960: $810-813$.

FLETCHER. O. J. - EIDSON, C. S. - KLEVEN, S. H.: Bursal lesions in chickens inoculated with Marek's disease vaccines. Avian Dis., 16, 1972: 153-162.

GREGER, J. L. - SCHWARTZ, R.: Subcellular changes in protein metabolism and magnesium content of the pancreas in rats fed two levels of dietary protein and magnesium. J. Nutrit., 104, 1974: $1618-1629$.

HLOŽÁNEK, I. - JURAJDA, V. - BENDA, V.: Disinfection of Marek's disease virus in poultry dust. Avian Pathol., 5, 1976 (in press).

JURAJDA, V. - KLIMEŠ, B.: Presence and survival of Marek's disease agent in dust. Avian Dis., 14, 1970: 188-190.

JURAJDOVÁ, J.: Koncentrace makroprvků, korelace a koeficienty jejich pomèrů v séru zdravých kuřat Rhode Island Red. Vet. Med. (Praha) (in press.).

KAPITOLA, J. - KÚCHEL, O.: Magnesium. Metabolismus a klinický význam. Thomayerova sbírka, SZN Praha 1968, 92 p.

IANSING, A. I. - ROSENTHAL, T. B. - AUB, M. H.: Ultrafilterable and nonfilterable calcium in normal, hyperplastic epidermis and squamous cell carcinoma. Arch. Biochem., 16, 1948: 189.

MAZUR, A. - HARROW, B.: Textbook of biochemistry. 10th ed., W. B. Saunders Co., Washington 1971, $727 \mathrm{p}$.

OKAZAKI, W. - PURCHASE, H. G. - NOLL, L.: Effect of different conditions on precipitation in agar between Marek's disease antigen and antibody. Avian Dis., 14, 1970: 532-537.

PURCHASE, H. G. - BIGGS, P. M.: Characterization of five isolates of Marek's disease. Res. Vet. Sci., 8, 1967: 440-449.

RUBIN, H.: Central role for magnesium in coordinate control of metabolism and growth in animal cells. Proc. Nat. Acad. Sci. USA 72, 1975: 3551-3555.

SAMADIEH, B. - BANKOWSKI, R. A. - CARROLL, E. J. : Electrophoretic analysis of serum proteins of chickens experimentally infected with Marek's disease agent. Am. J. Vet. Res., 30, 1969: 837-846.

ŠULA, J.: Některé novější, perspektivně významné hypotézy a poznatky $\mathrm{v}$ problémech karcinogeneze. Bioch. clin. bohemoslov., 3, 1974: 1-8.

WASHBURN, K. W. - EIDSON, C. S.: Changes in concentration of plasma proteins associated with Marek's disease. Poultry Sci., 49, 1970: 784-793.

ZÝKA, V.: Geochemické prostředí a zhoubné choroby I. Práce odboru prírodních věd Vlastivědného ústavu, Olomouc č. 22, 1972, 52 p. 